EDNA Rosenthal

The European Legacy/ISSEI

\title{
OPENING SPEECH MONDAY 11 JULY 2016 UNIVERSITY OF ŁÓDŹ, POLAND
}

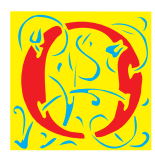
$\mathrm{n}$ behalf of ISSEI's organizing team and community, and the editors of The European Legacy, I want to express our deep thanks to the University of Łódź for hosting our $15^{\text {th }}$ conference. We want to thank Professor Antoni Różalski, Rector of the University, and Professor Tomasz Domański, Dean of the Faculty of International and Political Studies, for their support of the conference, and all who have generously given their time, hard work, and good advice in bringing this event to fruition. Our special thanks go to Mr. Tomasz Koralewski, director of VOLEO, for his invaluable help, and to Ms. Beata Gradowska and Ms. Rachel Ben-David for overseeing the administrative work. We owe our greatest debt of gratitude to Professor Krystyna Kujawińska Courtney for her faith in our joint endeavor, for her stamina and resourcefulness in bringing us here for a five-day meeting of minds. For a short time we will enjoy the beauties of this lovely city, and perhaps put aside our worries about the state of the world, of Europe, of our own country, of academia. A conference holds the promise of a wonderful adventure, as it is less an escape from out daily routine, as a chance to engage with our subjects in a new environment, with fellow academics with different histories and memories.

Before I say a few words on our theme, I have been asked by five people - whose names will be familiar to some of you, and who were unable to come to our gathering - to extend their personal greetings to you. Professor Ezra Talmor, founder of ISSEI and of our journal, The European Legacy; Professor David Lovell, my coeditor; Rachel Ben-David, coordinator of the academic programme; Professor Heinz Uwe-Haus, a long standing dedicated member of our Society; and Professor Yolanda Espina, our co-chair in our last conference, in Porto. 
For those who wonder what ISSEI stands for, allow me to read David Lovell's succinct description: "ISSEI was always more an ideal, than an organization with newsletters, organizing committees, and annual fees. It is an ideal of cooperative inquiry into the ideas of Europe, the idea of Europe itself, and . . . the influences of Europe on the rest of the world." ISSEI, that is, is an informal, voluntary association of those who are interested in attending our conferences and contributing to our journal.

So, what's new in the New Europe? To me the European Union is the embodiment of the New Europe. The vision of a united Europe, committed to the peaceful coexistence of erstwhile enemies, brings with it great responsibilities and great expectations. We are daily reminded of how momentous this vision is, how high the stakes of realizing it - by the growing resistance it provokes - resurgent nationalisms, demands for border controls, the calls for drastic measures to curb the waves of desperate immigrants from Africa and the Middle East, and now the political repercussions of the UK Referendum. Euroscepticism has of course accompanied European unification from the start, and has intensified in the past decade. But this vision, I believe, will in time overcome the backlash. No significant change - even ostensibly benign reforms of social and political arrangements - has ever come about without resistance or without some unexpected negative consequences. The history of every nation, of every community, attests to this, for the labour of civilization, as distinct from technological progress, is slow and unending.

"To have a new vision of the future, it has always first been necessary to have a new vision of the past," says British historian Theodore Zeldin, in an interview following the 1994 publication of his remarkable book, An Intimate History of Humanity. Adapting this to my purpose, I rephrase my belief: the European Union is a new vision of the future, which calls for a new understanding of the Old Europe. But what is the "old Europe"? To me the old Europe is very old, reaching back as far as history will take us; it is the centuries upon centuries of the evolution of the Western civilization. I do not deny that there are revolutions, or what appears as catastrophic ruptures with the past, but once a radical change has taken root in the public mind, there is a tendency to dismiss the past and to obscure the myriad links of the present state of affairs with what came before.

Umberto Eco, a few years before he died last February, stated his view of the New Europe in words that echo our theme: "It's culture, not war, that cements European Identity." And then declared: "We're now all culturally European." For Eco this shared European identity is the culmination of 
the long process of civilizing exchanges among those who were once total strangers and bitter enemies; it is something to be celebrated and defended, as the cumulative achievement of Europe's mixed origins - Greek, Roman, and Judeo-Christian. ${ }^{1}$

Now the same outlook was fiercely defended a century earlier by the early Modernists - James, Eliot, Pound, Joyce and their continental counterparts - who saw themselves as Europeans and cosmopolitans. Like James and Pound, Eliot came to Europe in 1914, made England his home, and famously declared in 1928 that he was a "classicist in literature, royalist in politics, and anglo-catholic in religion." While few were impressed by his political and religious allegiance, none in literary circles ignored his "classicist" stance. For the declared ambition of the literary avant-garde, as Eliot put it, was a question of "affirming forgotten standards, rather than setting up new idols."

Today, Eliot is mostly remembered for his poetry, especially for "The Waste Land" (1922) on Europe's spiritual desolation after the First World War, and some of the most memorable images of the modern city and modern psyche. But in his essays, which are less well known today, he promoted, like Eco, the idea of Europeanness as cultural identity, using the phrase "the mind of Europe" as a synonym for Western civilization as a whole. In his most influential essay, ${ }^{2}$ "Tradition and the Individual Talent" (1919), Eliot argued that the really new work of art was a function of its continuity rather than its rupture with the past. To him the "historical sense, which is a sense of the timeless, as well as of the temporal and of the timeless and of the temporal together, is what makes a writer traditional" (ibid). "Culture," as he put it, "is traditional, and loves novelty."3

Eliot, in fact, used "European" as the highest praise of writers, from the past and from the present, along with "catholic," "Latin," "traditional," and "universal," all of which terms implied a vibrant relationship with the past - with Homer, Aeschylus, Virgil, Dante, and Shakespeare. ${ }^{4}$ The uniqueness of a writer,

${ }^{1}$ G. Riotta, U. Eco, "It's culture, not war, that cements European identity," Guardian, 26 January 2012.

2 T. S. Eliot, "Tradition and the Individual Talent," in: Selected Essays (London: Faber and Faber 1951), 13-22. Frank Kermode sees it as "arguably his [Eliot's] most influential single essay" (introduction to Selected Prose of T. S. Eliot, ed. Frank Kermode [London: Faber and Faber, 1975], 11). Many critics agree that the essay is central to Eliot's criticism as a whole.

3 T. S. Eliot, "London Letter," The Dial, March 1921, 451.

${ }^{4}$ T. S. Eliot, "What Dante Means to Me," in: To Criticize the Critic and Other Writings (New York: Farrar, Straus and Giroux, 1965), 127. A few examples: "Marvell's best verse is the product of European, that is to say Latin, culture" ("Andrew Marvell," in: Selected 
of Dante, for example, he argued, was the outgrowth of his reliance on what came before him, on Aristotle and Aquinas.

As we know, Eliot's vision of cultural continuity was swept aside by the postwar rejection of the "old" order and grand Eurocentric narratives. Rupture, disruption, subversion - of the text, of the author, of the self, of the canon, of the disciplines - soon replaced the text-based New Criticism with the context-based Poststructuralist approaches. In Western universities the culture or canon wars, as they were called, led to the restructuring of curricula, with Cultural Studies gradually replacing literature departments. The boundaries of the disciplines were being redrawn, which change seemed to confirm, if not to accelerate, the decline of the humanities - the very subjects that form the bedrock of European identity, of any cultural identity.

And outside the universities, in the world at large? Well, at least here, in Europe, the boundaries were redrawn and the walls, real and symbolic, actually tumbled down, ushering in new possibilities, new freedoms. Yet the smaller the world became by the pull of globalization, and paradoxically the smaller Europe became through its unification and enlargement, the stronger the opposition, the louder the demands for closing the borders, for curbing individual freedoms, for defending one's national identity.

What do these and other conceptual, cultural and political shifts teach us? At the very least, they teach us that the dialectics or antinomies of inclusiveness and exclusiveness, like the dialectics of the old and the new Europe, demand a constant re-engagement with our ideas and ideals - of freedom, identity, democracy - with their origins, their development, and changing meanings.

To conclude: despite the setbacks, the resistance to, the understandable but perhaps exaggerated fear of the new, the vision of a united Europe delivers a priceless message to non-Europeans, such as myself: it brings with it the hope that people of other nations can decide one day to live in peace and settle their differences by learning to talk to each other, by learning each other's language and history, each other's way of thinking. As Europe, with its 28-strong Union, has done, non-Europeans may realize that war is the least civilized way of resolving disagreements and conflicts. That war is brutal and wasteful, and a sad reminder of our collective failure as Homo Sapiens.

Essays, 293); "Dryden is one of the tests of a catholic appreciation of poetry" ("John Dryden," in Selected Essays, 305); Hooker and Andrewes "were fathers of a national Church and they were Europeans" ("Lancelot Andrewes," in Selected Essays, 343). 
If Europe doesn't show the way, who will? This, then, is Europe's burden, its debt to its humanistic tradition - its Greek, Roman, Judeo-Christian tradition, and to the world beyond its shores and borders. "Cast thy bread upon the waters: for thou shalt find it after many days" (Ecc. 11:1), which in the original sounds thus:

\section{שלח לחמך על פני המים, כי ברוב הימים תמצאנו.}

Thank you all for coming to our conference. Thank you, the University of Łódź! Thank you, Łódź! wish all of us a wonderful conference! 